\title{
COMPARATIVE HISTOLOGICAL AND HISTOCHEMICAL STUDIES OF THE LACRIMAL GLANDS OF LOCAL SHEEP AND GOATS.
}

\author{
YAHYA AHMED MOHAMMED; SHAYMA ZUHAIR AMEEN and BAYAN SAEED SAADI \\ Department of Theriogenology, Anatomy and Physiology, Collage of Veterinary Medicine, \\ University of Duhok, IRAQ
}

Received: 17 April 2016; $\quad$ Accepted: 28 July 2016

\begin{abstract}
This research was carried out on the lacrimal glands (LGs) of male adult local sheep and goats. The aim of this study was to elucidate the normal histological and histochemical characteristics of the LGs. For this purpose, the histological specimens were stained with the H\&E, van Gieson's, periodic acid Shiff (PAS), diastase-PAS, alcian blue (AB) at pH 2.5 and $\mathrm{pH}$ 1, alcian blue-periodic acid Shiff (AB-PAS) and toluidine blue (TB). The present study revealed that the LGs of both animals were mixed tubuloacinar gland composed of secretory units (mainly serous and mucous as well as mucous acini opened into serous tubules) and excretory duct system. The mucous secretory units were predominant in sheep LGs comparing with those of goats LGs. The mucous cells in both animals contained mucins (neutral, carboxylated and sulphated) with the prevalence of carboxylated group in cells of sheep. The duct system in sheep and goats consisted of intercalated, intralobular, interlobular and main exceretory ducts. The lining epithelia of the interlobular and main excretory ducts in both animals had light cells, but the same ducts contained goblet cells in goat only. The mucin content of the goblet cells was similar to that of the glandular tissue of goats.
\end{abstract}

Key words: Lacrimal glands, sheep and goats, histology, histochemistry

\section{INTRODUCTION}

The tear film consisted of a superficial lipid layer, a middle aqueous layer and inner mucin (glycoprotein) layer covering the cornea (Walcott, 1998 and Davidson and Kuonen, 2004). The main function of lacrimal gland (LG) was the production of the aqueous layer (Stein and Hurwitz, 1996 and Samuelson, 2007). The LG also involved in the production of a component of the mucin layer of that film (Stein and Hurwitz, 1996 and Arango et al., 2001). The LG played an important role in the protection of the cornea and the conjunctiva from drying up and also nourished and lubricate the eye , contributed in metabolite exchange, protected the corneal surface from injuries caused by foreign bodies and had bactericidal and bacteriostatic properties (Stern et al., 2004; Zagon et al., 2012 and Al- Ramadan and Ali, 2012).

In literature, the morphology and histochmiestry of LGs had been described in ruminants including; sheep (Gargiulo et al., 1999 and Gargiulo et al., 2000) goats (Sinha and Calhoun, 1966) cattle (Pinard

Corresponding author: Dr. YAHYA AHMED MOHAMMED E-mail address: yhyam1967@gmail.com

Present address: Department of Theriogenology, Anatomy and Physiology, Collage of Veterinary Medicine, University of Duhok, IRAQ. et al., 2003b) buffalo (Maala et al., 2007; Shadkhast and Bigham, 2010) European bison (KlećkowskaNawrot et al., 2015).

The LGs of sheep and goat were regarded as a compound tubuloacinar gland, distinctly lobulated and highly vascularized (Sinha and Calhoun, 1966; Gargiulo et al., 1999). They were composed of serous, mucous and mixed acini (Daryuos and Ahmed, 2012).

The objectives of the present research were to describe the normal histological and histochemical features of the LGs of local sheep and goats.

\section{MATERIALS AND METHODS}

\section{Animals:}

Twelve LGs of adult male (six Karadi sheep and six local black goats) were immediately collected after slaughtering at Duhok abattoir, Kurdistan region, Iraq.

\section{Tissue preparation:}

Small samples $(0.5-1 \mathrm{~cm}$ thick) obtained from the LGs and fixed in buffered $10 \%$ formalin ( $\mathrm{pH} 7.0$ ) and Bounis fluid for 24 hours. The fixed specimens were dehydrated, cleared and then embedded in paraffin wax. Histological sections with 5-6 $\mu \mathrm{m}$ thick were prepared and stained with the following stains. 


\section{Stains:}

Histological study:

The following stains were utilized to demonstrate the general tissue structure:

1. Harris hematoxylin and eosin (H\&E) (Luna, 1967).

2. Van Gieson's (Luna, 1967).

Histochemical study:

It was conducted in order to identify the presence of carbohydrate types depending on the classification of Culling et al. (1985):

I. Glycogen or neutral polysaccharides (NPS).

II. Acid mucopolysaccharides (MPS) or Glycosaminoglycans (GSGs).

III. Glycoproteins.

For this purpose, the following dyes were applied:

1. Periodic acid Shiff (PAS) for identification of neutral polysaccharides (NPS) and different types of glycoproteins (Humason, 1972).

2. Diastase-PAS for establishment of glycoproteins (Humason, 1972).

3. Alcian blue at $\mathrm{pH} 2.5(\mathrm{AB}, \mathrm{pH} 2.5)$ for identification different types of MPS or GSGs, sulfated and carboxylated glycoproteins (Lev and Spicer, 1964 and Spicer et al., 1967).

4. Alcian blue at $\mathrm{pH} 1(\mathrm{AB}, \mathrm{pH} 1)$ for demonstration of sulfated MPS and sulfated glycoprotein (Lev and Spicer, 1964).

5. Alcian blue-PAS (AB-PAS) for detection of neutral and carboxylated glycoproteins (Mowry, 1956 and Lev and Spicer, 1964).

6. Toluidine blue (TB) for explore various types of MPS or GSGs (Humason, 1972).

The tissue sections were photographed by a photomicroscope (Olympus, Japan) and camera (Leica, Germany).

\section{RESULTS}

The histological and histochemical description of the LGs included both sheep and goat with some variations in between.

Histological study:

The present study showed that the LG was surrounded by relatively thick capsule. The components of the capsule comprehend collagen fibers, smooth muscle fibers, nerves, blood and lymphatic vessels. Layer of the adipose tissue was partially covering the capsule. The septa originated from the capsule dividing the gland into lobules with variable sizes. Individual or clusters of adipocytes were present in the septa and parenchyma of sheep only (Fig.1). The interstitial tissue was composed of fibroblasts, lymphocytes, plasma cells and capillaries.
In the current study, the LG was regarded as a mixed tubuloacinar gland consisting of secretory units and duct system.

\section{Secretory units:}

The LG comprised two types of secretory units; serous and mucous. The mucous secretory units were predominant in the gland of sheep, while the gland of goat had dominant serous ones. Both serous and mucous secretory units consisted of tubular and acinar portions. The acinar portions were more prevalent than that of tubular portions.

Serous secretory units:

The acinar portion was lined by single layer of pyramidal cells, whereas the tubular portion was lined with one layer of cuboidal cells. The cells of both portions had acidophilic cytoplasm. The cells of some acini had basophilic granules in their basal part. The nuclei of both portions were spherical in shape and basally located.

Mucous secretory units:

The lining epithelial cells of acinar and tubular portions were varied from tall to low pyramidal, respectively. Their cytoplasm was vacuolated and did not stain with eosin. The limits of the cells were distinct. The nuclei of both portions were oval or spherical in shape. Some mucous acini opened into the serous tubular portions. These patterns were located at the periphery of lobules in both animals (Fig. 2).

The myoepithelial cells were present between the secretory cells (serous and mucous) and the basement membranes. These cells had distinctive scant cytoplasm and flattened heterochromatic nuclei.

\section{Duct system:}

The duct system consisted of intercalated ducts, intralobular ducts, interlobular ducts and main excretory ducts.

Both intercalated and intralobular ducts were characterized by wide lumina. The lining cells of intercalated and intralobular ducts ranged from low cuboidal to cubodial, respectively. The cytoplasm of these ducts was scant and faintly stained with eosin. The nuclei had spherical shaped which occupied almost all the space of the cells.

The interlobular ducts were lined with double layer of cuboidal cells and surrounded by connective tissue of septa. The interlobular ducts of goats had goblets cells, whereas those of sheep were devoid from these cells.

The main excretory duct was left the gland, where it encircled by a sheath of collagenous fibers containing arterioles, venules, capillaries, lymphatics, nerves and 
aggregation of plasma cells. The main excretory ducts of sheep (Fig. 3) and goat (Fig. 4) were lined by stratified columnar epithelium containing numerous goblet cells in goat only.

The light cells were occurred in the epithelia of both interlobular and main excretory ducts of goats and sheep (Fig. 3 and Fig. 4). They possessed clear unstained cytoplasm with oval, pyknotic nuclei.

Histochemical study:

The histochemical study of the LGs of sheep and goats was summarized in tables 1 and 2 .

Table 1: Histochemical reactions of the lacrimal glands of sheep and goats.

\begin{tabular}{|c|c|c|c|c|c|c|c|}
\hline \multirow[t]{2}{*}{ Animals } & \multirow{2}{*}{$\begin{array}{c}\text { Types of secretory } \\
\text { units }\end{array}$} & \multicolumn{6}{|c|}{ Stains $*$} \\
\hline & & PAS & Diastase- PAS & $\overline{\mathrm{AB}}$ & $\mathrm{pH} 2.5$ & $\mathrm{AB} \mathrm{pH} 1$ & TB \\
\hline \multirow[t]{2}{*}{ Sheep } & Serous & - & - & & - & - & - \\
\hline & Mucous & +++ & +++ & & +++ & ++ & - \\
\hline \multirow[t]{2}{*}{ Goats } & Serous & - & - & & - & - & - \\
\hline & Mucous & ++ & ++ & & ++ & + & - \\
\hline
\end{tabular}

(*) : Include all the stains except, the AB-PAS

$(+++)$ : Intense reaction.

$(++)$ : Moderate reaction.

(+) : Faint reaction.

$(-) \quad$ : Negative reaction

Table 2: Types of carbohydrates within the lacrimal glands of sheep and goats.

\begin{tabular}{|c|c|c|c|c|c|c|}
\hline \multirow[t]{3}{*}{ Animals } & \multirow{3}{*}{$\begin{array}{l}\text { Types of } \\
\text { secretory } \\
\text { units }\end{array}$} & \multicolumn{5}{|c|}{ Types of carbohydrates } \\
\hline & & \multirow{2}{*}{$\begin{array}{c}\text { Glycogen } \\
\text { (NPS) }\end{array}$} & \multirow{2}{*}{$\begin{array}{c}\text { All types of } \\
\text { Glycosaminoglycans } \\
\text { (MPS) }\end{array}$} & \multicolumn{3}{|c|}{ Glycoproteins } \\
\hline & & & & $\begin{array}{c}\text { Mucin } \\
\text { (Neutral) }\end{array}$ & $\begin{array}{l}\text { Carboxylated } \\
\text { (Sialomucin) }\end{array}$ & $\begin{array}{c}\text { Sulphated } \\
\text { (Sulphomucin) }\end{array}$ \\
\hline \multirow[t]{2}{*}{ Sheep } & Serous & - & - & - & - & - \\
\hline & Mucous & - & - & + & +++ & + \\
\hline \multirow[t]{2}{*}{ Goats } & Serous & - & - & - & - & - \\
\hline & Mucous & - & - & + & ++ & + \\
\hline $\begin{array}{l}(+++): \mathrm{Ir} \\
(++): \mathrm{N} \\
(+): \mathrm{F} \\
(-) \quad: \mathrm{N}\end{array}$ & $\begin{array}{l}\text { nse occurre } \\
\text { derate occu } \\
\text { t occurreno } \\
\text { ative occur }\end{array}$ & & & & & \\
\hline
\end{tabular}

Serous secretory units:

The serous cells had negative reaction with PAS, diastase- PAS, AB pH 2.5, AB pH 1, AB-PAS. Also, there was no metachromachia, when they stained with TB. These reactions showed that the serous cells did not contain any kinds of carbohydrates in their cytoplasm.

Mucous secretory units:

The mucous cells reacted positively with PAS and diastase-PAS (purple) in sheep (Fig. 5) and goats (Fig. 6). These data revealed that the mucous cells did not contain glycogen granules and included glycoproteins. The mucous cells of sheep LGs were stained more intensely with PAS than those of goat, so the presence of glycoproteins were more abundant in sheep comparing with those of goat.

The mucous cells of sheep LGs reacted intensely with $\mathrm{AB} \mathrm{pH} 2.5$ (deep blue) and moderately with $\mathrm{AB} \mathrm{pH} 1$ (blue), whereas the same cells in LGs of goats reacted moderately and faintly (Fig. 7) with the pervious stains. The tissue sections of the sheep and goat LGs were stained with $\mathrm{AB}$ pH 2.5 (deep blue) and then followed by PAS (purple), most mucous cells reacted intensely with $\mathrm{AB}$ and faintly with PAS (Fig. 8).

All above-mentioned reactions revealed that the mucous cells of sheep and goats comprised neutral, carboxylated and sulphated glycoproteins, but the carboxylated group was predominant in sheep cells. The mucous cells had no metachromachia, when they stained with TB in both sheep (Fig. 9) and goats. This was indication for the absence of glycosaminoglycans (MPS).

Goblet cells:

The goblets cells within the epithelia of intralobular and main execratory ducts of goats were stained moderately with PAS and diastase-PAS (Fig. 10), strongly with $\mathrm{AB}$ pH 2.5 (Fig. 11) and faintly with $\mathrm{AB} \mathrm{pH} \mathrm{1(Fig.} \mathrm{12).} \mathrm{They} \mathrm{had} \mathrm{negatively} \mathrm{reactions} \mathrm{with}$ TB. These reactions showed that the goblet cells contained different types of glycoproteins with the prevalence of carboxylated group.

Light cells:

The light cells had no any reactions with stains applied for histochemical study (Fig. 10 and Fig. 11). 


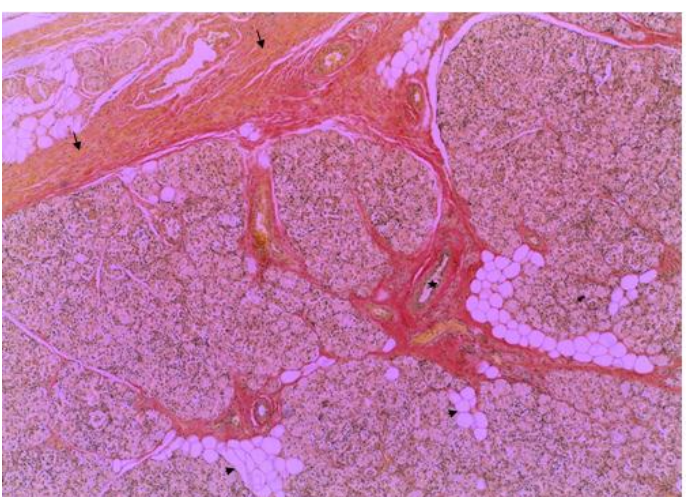

Figure 1: A photograph of the capsule and septa of sheep lacrimal gland showing smooth muscle fibers (arrows). Interlobular ducts (star). Adipocytes (arrow heads).

Stain: Van Gieson's X 4

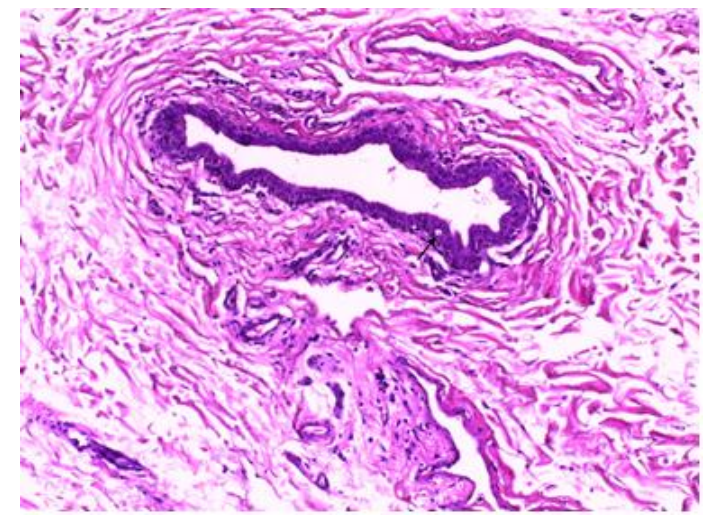

Figure 3: A photograph of the main excretory duct of sheep showing light cells (arrow). Stain: H\&E X 10

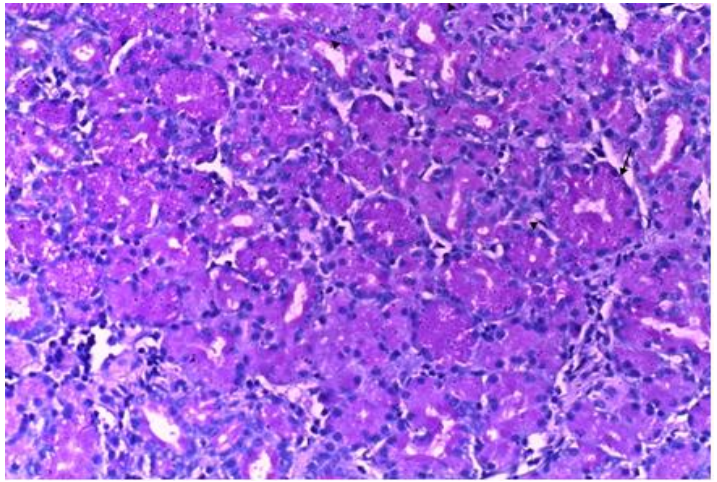

Figure 5: A photograph of sheep lacrimal gland showing cells of mucous secretory units stained intensely purple; acinar portion (arrow) \& tubular portion (arrow head).

Stain: PAS X 20

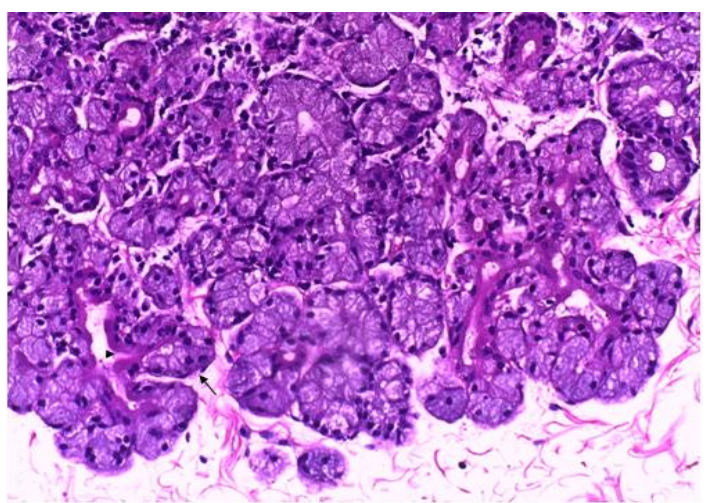

Figure 2: A photograph of sheep lacrimal gland showing mucous acinus (arrow). Serous tubule (arrow head).

Stain: H\&E. X 20

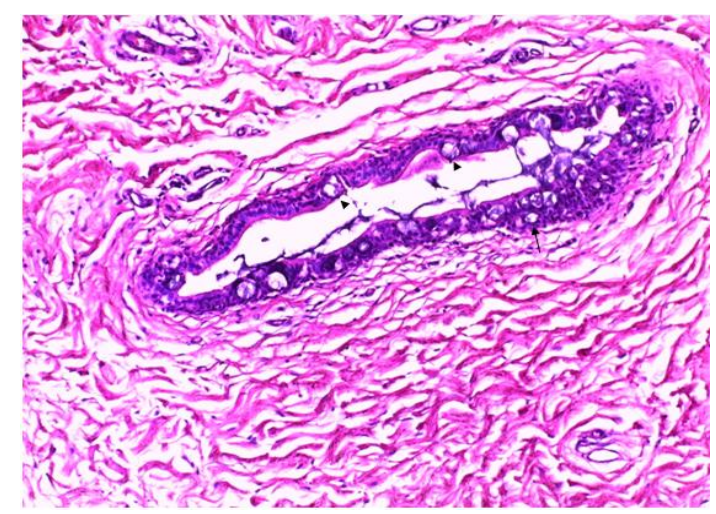

Figure 4: A photograph of the main excretory duct of goat showing goblet cells (arrow heads). Light cell (arrow).

Stain: H\&E. X 10

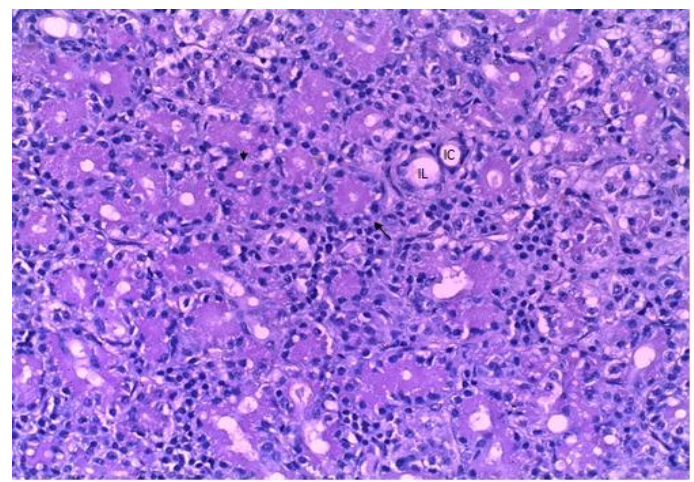

Figure 6: A photograph of goat lacrimal gland showing cells of mucous secretory units stained moderately purple; acinar portion (arrow) \& tubular portion (arrow head). Intercalated (IC) and intralobular ducts (IL). Stain: PAS X 20 


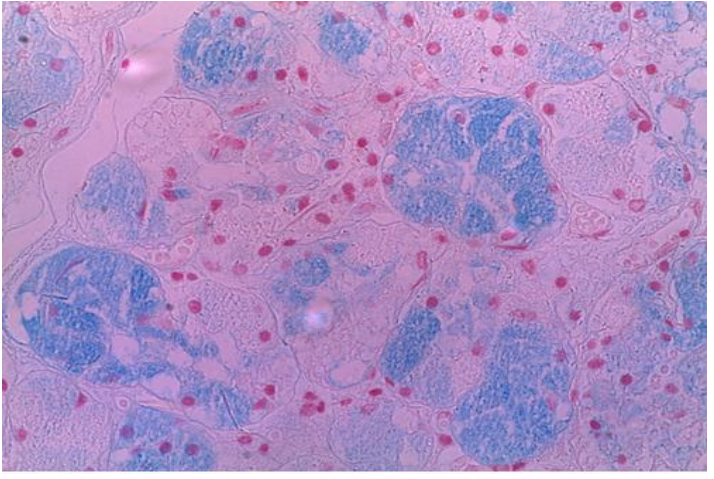

Figure 7: A photograph of goat lacrimal gland showing cells of mucous secretory units stained faintly blue.

Stain: AB pH 1 X 40

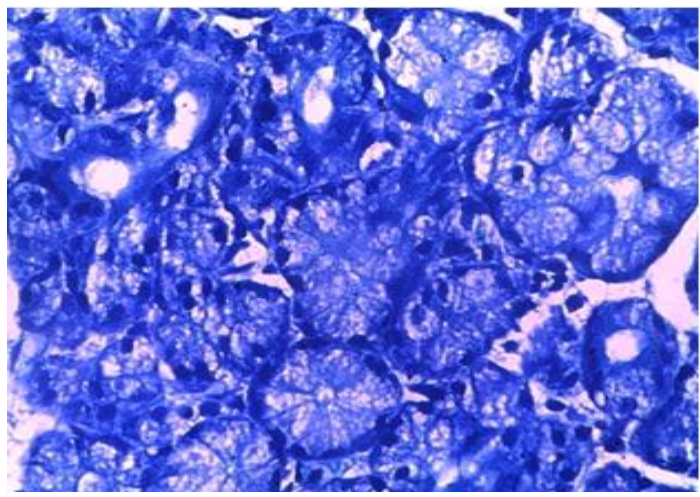

Figure 9: A photograph of sheep lacrimal gland showing absence of metachromacia. Stain: TB X 40

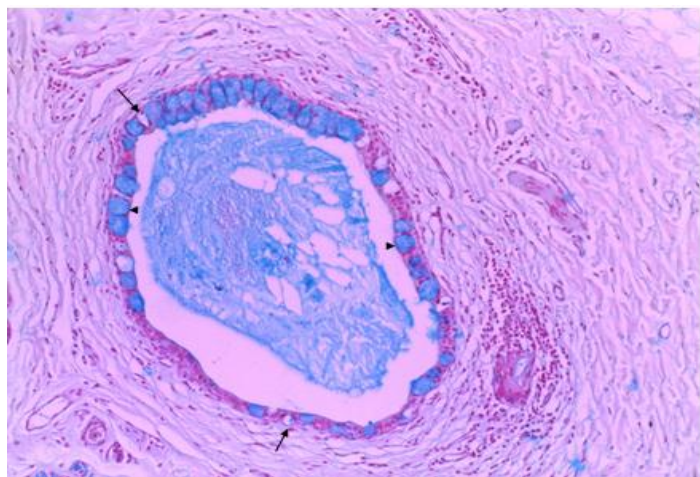

Figure 11: A photograph of the main excretory duct of goat showing goblet cells stained intensely blue (arrow heads). Light cells (arrows). Stain: AB pH 2.5 X 10

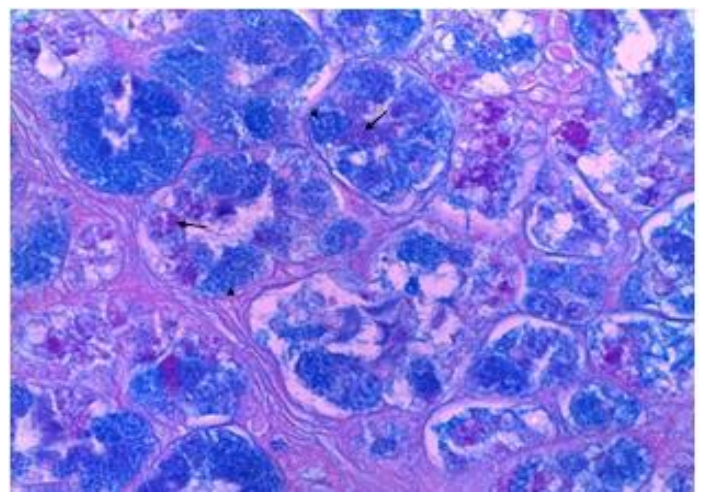

Figure 8: A photograph of sheep lacrimal gland showing cells of mucous secretory units stained intensely deep blue (arrow heads) and purple (arrows).

Stain: AB-PAS X 40

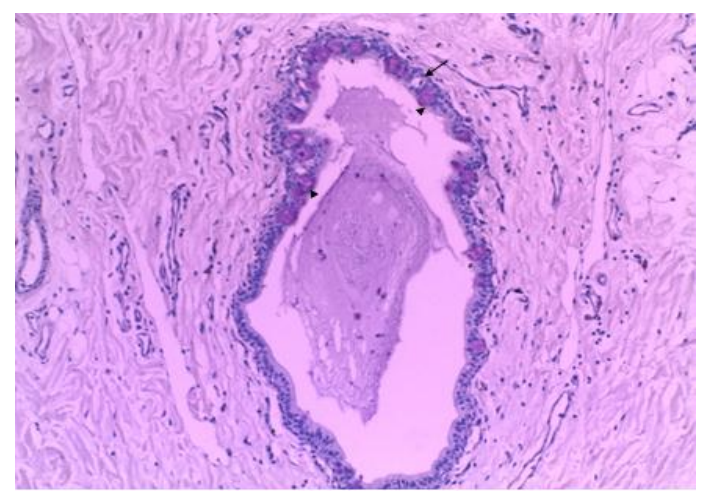

Figure 10: A photograph of the main excretory duct of goat showing goblet cells stained moderately purple (arrow heads). Light cell (arrow).

Stain: Diastase - PAS X 10

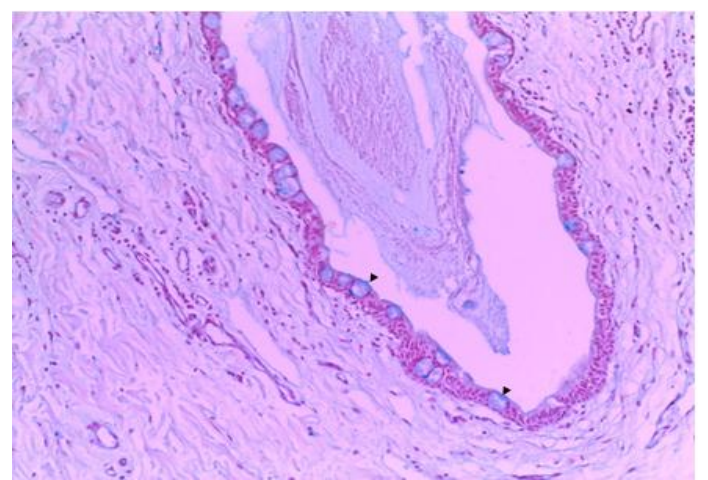

Figure 12: A photograph of the main excretory duct of goat showing goblet cells stained faintly blue (arrow heads).

Stain: AB pH 1 X 10 


\section{DISCUSSION}

In the current study, the histological and histochemical examinations of the LGs of sheep and goats observed similarities and differences, when they were compare with the other species.

In the present research, the capsule of the LG was partially covered by adipose tissue, while this tissue occurred beneath the capsule of alpaca (KlećkowskaNawrot et al., 2015). On the other hand, individual or clusters of adipocytes penetrated the parenchyma and septa were observed in the present study. This finding was agreement with those of the LG of alpaca (Klećkowska-Nawrote et al., 2015). The adipose tissue enclosed the eye ball and other orbital tissue structures which act as a cushion (Koorneef, 1979).

Our observation revealed that the smooth muscle fibers were restricted to the capsule of the LGs of both animals. Daryuos and Ahmed (2012) concluded that the smooth muscle fibers occurred in the capsule, as well as around the interlobular and main excretory ducts might facilitate the drain of secretion from the gland.

The present investigation pointed that the numerous plasma cells infiltrated in the gland interstitium. These cells played an important role in immune system (Walcott, 1998). In this respect, Moore and Whitley (1984); Rebhun (1984) and Dartt (2009) recorded that activated plasma cells secreted immunoglobulins protecting the sensitive mucosa and the ocular surface of the eye against disease, including many upper respiratory diseases in ruminants. The plasma cells in human LG produced predominantly IgA type (Franklin et al., 1973). The source of this immunoglobulin in rat tears did not come from the serum, but come from the local synthesis within the gland interstitium (Sullvian and Allansmith, 1984). IgA immunoglobulin was transported across the secretory cell membranes and finally reached the glandular lumen (Walcott, 1998).

In according with the previous studies in the LGs of Philippine water buffalo (Maala et al., 2007) Roe deer (Klećkowska-Nawrot et al., 2013) and camel (Ibrahim, 2015), the myoepithelial cells in the present work were situated between the secretory cells and the basement membranes. Contraction of these cells was thought to "squeeze" the secretion away from the secretory units into the duct system (Walcott, 1998 and Samuelson, 2007).

The morphological features of the secretory units in present investigation were similar to those of Abbasi, et al. (2015) in sheep, since comprised both serous and mucous. Daryuos and Ahmed (2012) mentioned that the LGs in sheep and goats contained mixed acini (possessed both serous and mucous cells) in addition to the serous and mucous acini. According to
Klećkowska-Nawrot et al. (2013) and KlećkowskaNawrot et al. (2015), the LGs in Roe deer and European bison had been considered to be serous in nature.

Pinard et al. (2003b) demonstrated that the LGs of Americans bison and cattle consisted of acini containing PAS positive granules and serous tubules. Our results exhibited that some mucous acini opened into serous tubules. The cross and oblique sections of these secretory units were gave a mistaken appearance which they comprised both serous and mucous cells.

Similar results were obtained by Gargiulo et al. (1999); Daryuos and Ahmed (2012) in small ruminants and Ibrahim (2015) in camel, the duct system in the present investigation was composed of intercalated ducts, intralobular ducts, interlobular ducts and main excretory ducts. Unlike that, the duct system of rabbit LG comprised the intercalated, intralobular, interlobular, intralobar, interlobar and main excretory ducts (Ding et al., 2010).

The comparison of the duct system between the LGs in our study and the salivary glands in other studies (Elewa et al., 2010 and Muthukrishnan et al., 2013) showed that the intercalated and interalobular ducts were characterized by wide lumina and absence of the striated ducts. The lack of striated ducts in the LGs might be because the lacrimal secretion was isotonic, rather than hypotonic, as in the case of saliva (Ding et al., 2010).

In the present work, the goblet cells were found in the lining epithelia of interlobular and main excretory ducts of goats only, while the former cells observed within the similar ducts of sheep and goats (Daryuos and Ahmed, 2012).This was due to breed differences between Iraqi sheep.

In our research, the mucous cells of LGs of both sheep and goat reacted positively with PAS. Furthermore, there was no any change in the staining, when we used diastase prior PAS. These data revealed that the mucous cells did not contained glycogen granules (NPS) and included glycoproteins. Mc Manus (1946) had stated that PAS stained glycogen as well as mucins, but tissue could be predigested with diastase to remove glycogen showing PAS an important mucin stain. Moreover, the PAS technique was especially sensitive to demonstrate neutral mucin and acid mucin which comprised significant quantities of sialic acid (Ali et al., 2012).

Our study was identified that the mucous cells of sheep LGs reacted intensely with $\mathrm{AB}$ pH 2.5 and moderately with $\mathrm{AB} \mathrm{pH} \mathrm{1,} \mathrm{whereas} \mathrm{the} \mathrm{same} \mathrm{cells} \mathrm{in}$ LGs of goats reacted moderately and faintly with the previous stains. When we stained the LGs of both sheep and goats with AB-PAS, most mucous cells reacted intensely with $\mathrm{AB}$ and faintly with PAS. 
The a formentioned reactions revealed that the mucous cells of sheep and goats contained neutral, carboxylated (silomucin) and sulphated (sulphomucin) glycoproteins with the predominance of carboxylated group in the cells of sheep. Lev and Spicer (1964) used $\mathrm{AB}$ at $\mathrm{pH} 2.5$ and $\mathrm{pH} 1$ to distinguish between acid and sulphated mucopolysaccharids. Also, Spicer et al. (1967) explained that the carboxyl $(\mathrm{COOH})$ groups stained well at $\mathrm{AB} \mathrm{pH} 2.5$, while sulphate $\left(\mathrm{OSO}_{3} \mathrm{H}\right)$ groups might stain poorly. Otherwise, Mowry (1956) used AB-PAS to differentiate between the acid and neutral mucins.

The mucous and seromucous glandular cells in sheep LG contained acidic glycoconjugates, mainly sulphated (Gargiulo et al., 2000) and the mucous cells in alpaca LG comprised neutral and acid glycoproteins; sulphated and carboxylated (Kleckowska-Nawrot et al., 2015). The mucin was constitute the inner layer of the tear film (Walcott, 1998 and Davidson and Kuonen, 2004) which secreted from the LG as well as the corneal and conjunctival epithelia (Arango et al., 2001).This substance acts as a protective agent and produced a further reduction in surface tension. It also showed greater affinity for the water / oil interface than protein (Holly and Lemp, 1989; Gargiulo et al., 2000 and Arango et al., 2001). Additionally, the ocular mucin played a role in the treatment of dry eye syndromes and ocular surface microbial infections (Davidson and Kuonen, 2004).

The serous cells of sheep and goat had negative reactions with all stains using for histochemical study, so they did not contain any type of carbohydrates and their secretion was proteintous in nature. At ultrastructure level, the serous cells of sheep LG were regarded as protein -secreting cells, because contained all structural components of protein synthesis, e.g. extensive rough endoplasmic reticulum, well-developed Golgi apparatus and secretory granules (Gargiulo et al., 1999).

During the course of this finding, the goat LGs contained numerous serous secretory units comparing with mucous ones. Furthermore, based on the histochemical analysis, the content of glycoprotein in mucous secretory units was less abundant. From these factors, the LG might produce small amount of mucin in their secretion. Therefore, the presence of goblet cells within the epithelia of their ducts would compensate this deficiency. Kim et al. (1991) stated that the mucin with a high molecular weight glycoprotein was secreted by epithelial mucosal cells, particularly the goblet cells.

Depending on the histological and histochemical studies in the present work, the cytoplasm of light cells in both animals did not stain with routine and histochemical dyes. Furthermore, the nuclei of these cells hadpyknotic appearance. From these criteria, the light cells might be undergoing apoptosis. Junqueira and Carneiro (2005) and Choudhury et al. (2012) recorded that the apoptotic cells displayed prominent morphological changes during apoptotic process, one of these; breakdown of chromatin in the nucleus often lead to nuclear condensation.

\section{CONCLUSION}

In this study, the morphological structure of LGs could be reflected on their function. The LGs produced seromucous secretion, because they contain both serous and mucous secretory units. Furthermore, our results revealed the presence of mucin within the mucous cells. This substance was essential for maintaining the normal corneal as well as the optical integrity of the eye (Stein and Hurwitz, 1996).

\section{REFERENCES}

Abbasi, M.; Karimi, H. and Gharzi, A. (2015): Preliminary anatomical and histological study of lacrimal gland in Lori sheep. Journal of Veterinary Science and Technology 5(1): 1-4.

Ali, U.; Nagi, A.H.; Naseem, N. and Ullah, E. (2012): Mucinhistochemistry in tumours of colon, ovaries and lung. J. Cytol. Histol. 3: 163-167.

Al-Ramadan, S.Y. and Ali, A.M. (2012): Morphological studies on the third eyelid and its related structures in the one-humped camel (Camelusdromedarius). J. Vet. Anat. 5: 71-81.

Arango, M.E.; Li, P.; Komatsu. M.; Montes, C.; Carothers Carraway, C.A. and Carraway, K.L. (2001): Production and localization of Muc4/ Sialomucin complex and its receptor tyrosine kinase Erb B2 in the rat lacrimal gland. IOVS 42: 2749-2756.

Choudhury, J.D.; Kumar, S.; Mayank, V.; Mehta, J. and Bardalai, D. (2012): A review on apoptosis and its different pathway. International Journal of Biological and Pharmaceutical Research. 3(7): 848-861.

Culling, C.F.A.; Alison, R.T. and Barr, W.T. (1985): Cellular pathology technique. 4th ed. Butterworth and Co. Ltd., London. pp 214216.

Dartt, D.A. (2009): Neural regulation of lacrimal gland secretory processes: Relevance in dry eye disease. Prog. Retin. Eye Res. 28:155-177.

Daryuos, M.M. and Ahmed, N.S. (2012): Comparative histological and morphometrical study of the lacrimal apparatus of Awasi sheep and native black goat. Kufa Journal for Veterinary Medical Sciences 3(2): 41-56.

Davidson, H.J. and Kuonen, V.J. (2004): The tear film and ocular mucins. Vet. Ophthal. 7: 7177.

Ding, C.; Parsa, L.; Nandoskar, P.; Zhao, P.; Wu, K. and Wang, Y. (2010): Duct system of the rabbit lacrimal gland: structural characteristics 
and role in lacrimal secretion. Invest. Ophthalmol. Vis. Sci. 51: 2960-2967.

Elewa, Y.H.; Bareedy, M.H.; Abuel-Atta, A.A.; Ichii, O.; Otsuka, S.; Franklin, R.; Kenyon, K. and Tomasi, T. (2010): Immunohistologic studies of human lacrimal gland: localization of immunoglobulins, secretory component, and lactoferrin. J. Immunol. 110: 984-992.

Gargiulo, A.M.; Coliolo, P.; Ceccarelli, P. and Pedini, V. (1999): Ultrastructural study of sheep lacrimal gland. Vet. Res. 30: 345-351.

Gargiulo, A.M.; Dall'Aglio, C.; Coliolo, P.; Ceccarelli, P. and Pedini, V. (2000): Complex carbohydrate histochemistry and ultracytochemistry. Anat. HistolEmbryol, 29: 19-23. 665.

Holly, F.J. and Lemp, M.A. (1989): Tear physiology and dry eyes. Surv. Ophthalmol. 22: 69-87.

Humason, L. (1972): Animal tissue techniques. 3rd ed., W.H. Freeman and Company. San Francisco. pp 317-329.

Ibrahim, Z.H. (2015): Study of season-based histomorphometric variations in lacrimal gland of camel (Camelusdromedarius). Inter. J. Vet. Sci. 4(3): 123-126.

Junqueira, L.C. and Carneiro, M.S. (2005): Basic Histology: Text and Atlas. 11th ed. Mc Grow Hill, New York. PP 64.

Kim,Y.S.; Gum, J.R. Byrd, J.C. and Toribara, N.M. (1991): The structure of human intestinal apomucins. Am. Rev. Respir. Dis. 144: 10-14.

Klećkowska-Nawrot, J.; Nowaczyk, R.; GozdziewskaHariajczuk, K.; Szara, T. andOlbrych, K. (2015): Histology, histochemistry and fine structure of the Harderian gland, lacrimal gland and superficial gland of the third eyelid of the European bison, Bison bonasusbonasus (Artiodactyla: Bovidae). Zoologia (Curibiba) 32(5): 380-394.

Klećkowska-Nawrot, J.K.; Marycz, K.; Czogała, J.; Kujawa, K.; Janeczek, M.; Chrószcz, A. and Brudnicki, W. (2013): Morphology of the lacrimal gland and superficial gland of the third eyelid of Roe deer (Capreoluscapreolus L.). Pak. Vet. J. 2: 139-144.

Koorneef, L. (1979): Orbital septa: anatomy and function. Ophthalmology 86: 876-885.

Lev, R. and Spicer, S.S. (1964): Specific staining of sulphate groups with alcian blue at low $\mathrm{pH}$. J. Histochem. Cytochem. 12: 309.

Luna, L.G. (1967): Manual of histological staining methods, 3rd ed., McGraw-Hill book Company. New York. pp 34,76.

Maala, C.P.; Cartagena, R.A. and De Ocampo, G.D. (2007): Macroscopic histological and histochemical characterization of the lacrimal gland of the Philippine water buffalo
(Bubalusbubalus). Philippine Journal of Veterinary Medicine. 44(2): 69-75.

McManus, J.F. (1946): Histological demonstration of mucin after periodic acid. Nature 158: 202

Moore, C.P. and Whitley, R.D. (1984): Ophthalmic diseases of small domestic ruminants. Vet. Clin.North.Am. Large Anim. Pract. 6: 641665.

Mowry, R.W. (1956): Alcian blue techniques for the histochemical study of acidic carbohydrates. J. Histochem. Cytochem.4: 407.

Muthukrishnan, S.; Basha, S.H.; Ramesh, G.; Ushakumary; Rajathi, S. and Kumaravel, A. (2013): Histomorphology of Parotid Salivary Gland in Sheep (Ovisaries). Indian Journal of Veterinary Anatomy 25(2): 92-93.

Pinard, C.L.; Weiss, M.L.; Brightman, A.H.; Fenwick, B.W. and Davidson, H.J. (2003b): Normal anatomical and histochemical characteristics of the lacrimal glands in the American bison and cattle. Anat. Histol. Embryol. 32: 257-262.

Rebhun, W.C. (1984): Ocular manifestations of systemic disease in cattle. Vet. Clin. North. Am. Large Anim. Pract. 6: 623-639.

Samuelson, D.A. (2007): Text book of Veterinary Histology, Saunders an imprint of Elsevier Inc. pp 511.

Shadkhast, M. and Bigham, A.S. (2010): A HistoAnatomical study of dorsal lacrimal gland in Iranian river buffalo. Vet. Scan. 5: 1-5.

Sinha, R.D. and Calhoun M.L. (1966): A gross, histologic and histochemical study of the lacrimal apparatus of sheep and goats. Am. J. Vet. Res. 27: 1633-1640.

Spicer, S.S.; Horn, R.G. and Leppi, T.J. (1967): The connective tissue. Ed. Wagner, W.E. International Academic Monograph., No. 7 Williams and Wilkins, Biltimore.

Stein, R. and Hurwitz, J.J. (1996): Anatomy and physiology of tear secretion. In: Hurwitz J.J. ed. The lacrimal system. Lippincott -Raven, New York, USA, pp. 1-8.

Stern, M.E.; Gao J.; Siemasko, K.F.; Beuerman, R.W. and Pflugfelder, S.C. (2004): The role of the lacrimal functional unit in the pathophysiology of dry eye. Exp. Eye Res. 78: 409-416.

Sullivan, D.A. and Allansmith, M.R. (1984): Source of $\operatorname{IgA}$ in tears of rats. Immunology 53: 791799.

Walcott, B. (1998): The lacrimal gland and its veil of tears. Physiology 13: 97-103.

Zagon, I.S.; Campbell, A.M.; Sassani, J.W. and McLaughlin, P.J. (2012): Spontaneous episodic decreased tear secretion in rats is related to opioidergic signaling pathways. Invest Ophthalmol. Vis. Sci. 53: 3234-3240. 


\section{دراسة نسجية ونسجوكيميائية مقارنة للغدد الدمعية للأغنام والماعز المحلية}

يحيى احد محدد ، بيان سعبل سعدي ، شبياء زهير (مبين

اجري هذا البحث على الغدد الدمعية لذكور الاغنام والماعز البالغة المحلية. استهدفت الدراسة الحالية ايضاح الخصائص النسجية

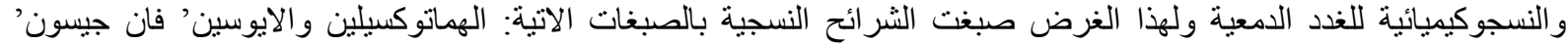

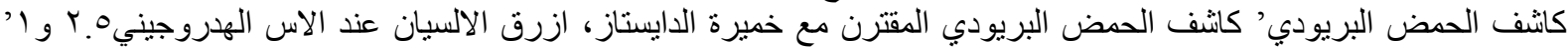

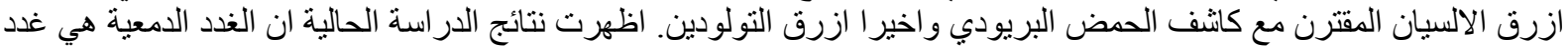

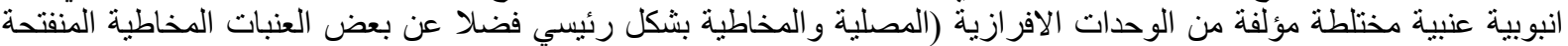

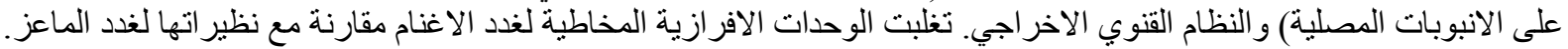

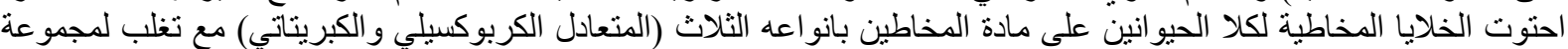

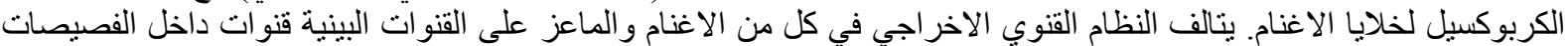

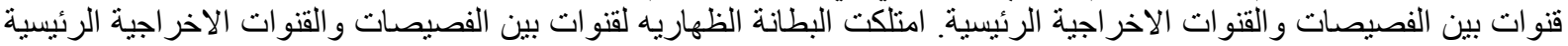

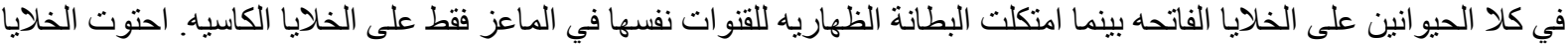

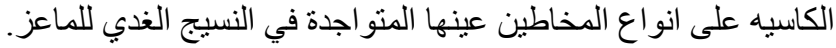

